\title{
10 Years of Polish Membership in the European Union Structures. Was It Worth It?
}

\begin{abstract}
Poland had to meet various political, legal and economic criteria in order to become a member of the European Union; the EU itself also had to prepare for it in institutional and financial respect. Although fulfilling acquis communautaire standards, then accession negotiations and completion of formalities lasted 10 years and the anti-EU campaign before a national referendum about Polish integration with the EU caused serious doubts and concerns connected with the accession, still on the 1 May 2004 Poland became a member of the EU. Now, after 10 years of membership there are several questions how Poland has used its presence in this organization. Has it been a time of prosperity and success or rather a failure and a historical mistake? What and how has Poland been changed over this time? Have social doubts connected with the EU integration been allayed? These are just a few questions raised in this article and the author tries to answer them.
\end{abstract}

Keywords: European Union, Poland, membership, benefits and costs of membership

Many counties are proud to be members of the European Union despite the fact that in order to become such one must fulfill high legal, economic and political standards. What is more, the whole access procedure may last many years and still there is no guarantee that a particular country will be accepted. This mainly depends on the political will of the leaders of the EU countries, general social moods within the EU and finally a widely understood readiness of the EU to accept new members. Despite all these, the European Union is considered to be appealing; and not only does it not contract ${ }^{1}$ but also admits more and more new member

1 Only from time to time some conservative leaders, for example from Great Britain, make speeches about the possibility of leaving the EU structures if the Community fails to introduce firm reforms. Although these are voices of important people and they reflect the social moods of the United Kingdom, one cannot take them for granted. They are often a result of the necessity to in- 
states. Still, in spite of economic crisis and crisis of trust, this organization has a unique ability to attract.

Also Poland for many reasons decided to prioritise membership in the EU in its foreign policy straight after the beginning of system transformations in 1989. On 16 December 1991 the Europe Agreement was signed which regulated the relations between Poland and member states and gave Poland the status of an associated country. This, however, failed to satisfy Polish political leaders and on 8 April 1994 Poland submitted an application for full membership in the European Union. 10 years later, on 1 May 2004, after many reforms, tough negotiations of Accession Treaty ${ }^{2}$ and Polish citizens' agreement expressed in referendum ${ }^{3}$ Poland officially joined a group of strongly united European countries.

The current year of 2014 is a symbolic $10^{\text {th }}$ anniversary of Poland's joining the structures of the European Union and it is undeniably a remarkable date. No wonder that all over Poland there have been and will be various events emphasizing the importance of this happening. Concerts, festivals, picnics, TV programmes, conferences or publications are just some examples. Their aim was to make Polish society aware of how much Poland and the Poles owe the EU. Although there are many benefits of being a member of the EU, it is not always the case that everything goes according to Polish expectations or interests. The article below is, there-

clude opinions of various intraparty fractions in official speeches of the leaders and the anti-Union one within the ruling Conservative Party is currently very strong. If Great Britain decided to leave the European Union, it would lose much more than it could gain by doing it.

2 Full text of Accession Treaty with documents of the European Parliament, European Commission and Council of the EU on this enlargement [in:] OJ L 236, 23.09.2003.

3 The so-called accession referendum took place between 7-8 June 2003 and the Poles answered the question: "Do you agree on Poland's joining the European Union?" The National Electoral Commission announced 58.85\% turnout of voters (that is 17584085 out of 29864969 people voted). $77.45 \%$ of them (that is 13514 872) answered "yes", and $22.55 \%$ (that is 3935 $655)$ answered "no". There were 126187 invalid votes ( $0.72 \%$ of the total number of votes). Since more than a half of people entitled to vote took part in the referendum and there were no serious faults during the voting (except for two constituencies in Ełk and Wrocław), Supreme Court announced the referendum valid. See: Obwieszczenie Państwowej Komisji Wyborczej z dnia 21 lipca 2003 roku o skorygowanym wyniku ogólnokrajowego referendum w sprawie wyrażenia zgody na ratyfikację Traktatu dotyczącego przystąpienia Rzeczypospolitej Polskiej do Unii Europejskiej, Dz.U. RP 2003 No. 132/1223; Uchwała Sądu Najwyższego z dnia 16 lipca 2003 roku w przedmiocie ważności referendum ogólnokrajowego w sprawie wyrażenia zgody na ratyfikację Traktatu dotyczącego przystąpienia Rzeczypospolitej Polskiej do Unii Europejskiej, wyznaczonego na dzień 8 czerwca 2003 roku, w którym głosowanie przeprowadzono w dniach 7 i 8 czerwca 2003 roku, doc. no III SW 144/03; Uchwała Państwowej Komisji Wyborczej z dnia 21 lipca 2003 roku w sprawie skorygowania wyników głosowania w referendum ogólnokrajowym w sprawie wyrażenia zgody na ratyfikację Traktatu dotyczącego przystąpienia Rzeczypospolitej Polskiej do Unii Europejskiej, Przegląd Wyborczy. Biuletyn informacyjny, 2003, No. 7-8, pp. 9-11. 
fore, to display its readers the arguments for and against the EU and to answer the question whether it was worth joining it.

\section{Positive aspects of Polish membership in the EU}

Combining the arguments of those in favour and against membership in the EU is both easy and difficult. Easy as we could discuss the pros for many days, there are many books and articles about how much Poland owes the EU; moreover, the media are still informing the public about more and more accomplished investments. There are many facts and data about it. One the other hand, this much information makes everyone have their own opinion about the European Union - from almost uncritical to totally negating the very sense of existence of this organization. What is a huge benefit for some, for others may be an argument proving that 1 May 2004 was a big historical mistake. Still, the author of this article will try to discuss cons and opportunities as well as costs and threats of Poland's joining the EU from an objective observer's perspective. The author will enumerate only those most often appearing arguments of both sides as it is impossible to include all of them in such a short piece of text.

\section{Political arguments}

Although it is hard to measure and verify them, we shall start with political arguments put forward by those in favour of the European Union. There are quite a few of such. First of all, Poland's joining the structures of the European Union in 2004 contributed to reinforcement of Polish position on the international arena. Our country became more recognizable in international relations and joining strongly uniting European countries made Poland more trustworthy in the eyes of third countries and other international organizations. Thanks to this, Poland started to be considered a stable and predictable subject as joining the EU required fulfilling high political, legal and economic standards ${ }^{4}$.

\footnotetext{
4 The so-called Copenhagen Criteria: the existence of institutions which guarantee stable democracy; rules of law, respecting the human rights, respecting the rights of minorities, trade economy which is able to meet the requirements of competition and free market; the ability to adopt acquis communautaire; the ability to meet the requirements of political, economic and currency union. These rules were soon written in Treaty on European Union. See: European Council in Copenhagen, 21-22 June 1993, Conclusions of the Presidency, http://europa.eu/rapid/press-
} 
The second argument in favour of the European Union is in some way related to the first one. The ambition to become the EU member and later the fact of joining the organization was a kind of trigger for Polish political leaders at that time to revalue priorities of Polish foreign policy with its key assumptions and spheres of action. In reality, joining the EU gave Poland an ability to influence EU foreign policy and its external actions in the world (e.g. co-authorship of EU Eastern Policy). Since 2004 Poland has been one of just few countries which emphasize the importance of one common voice of the whole EU in international relations (e.g. during UN forum or towards Russia). Moreover, thanks to being a member of the EU the interests of Polish foreign policy have been enlarged and activated (e.g. South-East Asia).

Thirdly, the enlargement of the European Union in 2004 enabled Poland to participate in work of European institutions, organs and agencies; the country gained voting rights. There are Polish representatives in among others European Parliament, European Commission, Committees of the Regions and Economic and Social Committee, etc ${ }^{5}$. The Polish government intensively work on forums of Council of the European Union and European Council. As a country, we have a real possibility to influence the actions of the EU, influence how it evolves, what law is accepted, in what form and procedure. If the projects of legal acts are against Polish interests, the country can lobby against them or take other preventive steps. Thanks to our population and the size of our economy, the voice of Poland within the EU is well heard. Naturally, it is not always possible for Poland to force its own ideas and solutions ${ }^{6}$. Still, we do not give up easily, which can proved by accepted EU multiannual financial framework for the years 2014-20207.

release_DOC-93-3_en.htm?locale=en; art 6 par. 1 of Consolidated version of the Treaty on European Union (after Amsterdam), OJ C 340, 10.11.1997.

5 See: Permanent Representation of the Republic of Poland to the European Union in Brussels, Polska w Brukseli, http://brukselaue.msz.gov.pl/pl/polska_w_brukseli/, (accessed 1.08.2014).

6 For example: the definition of vodka, ban on producing and selling flavoured cigarettes or content of tar yield in smoke. See: Regulation (EC) No 110/2008 of the European Parliament and of the Council of 15 January 2008 on the definition, description, presentation, labelling and the protection of geographical indications of spirit drinks and repealing Council Regulation (EEC) No 1576/89, OJ L 39, 13.02.2008; Directive 2014/40/EU of the European Parliament and of the Council of 3 April 2014 on the approximation of the laws, regulations and administrative provisions of the Member States concerning the manufacture, presentation and sale of tobacco and related products and repealing Directive 2001/37/EC, OJ L 127, 29.04.2014; Commission Implementing Regulation (EU) No 1321/2013 of 10 December 2013 establishing the Union list of authorised smoke flavouring primary products for use as such in or on foods and/or for the production of derived smoke flavourings, OJ L 333, 12.12.2013.

7 See: Ministry of Foreign Affairs (MSZ), Wieloletnie Ramy Finansowe, http://www.msz.gov. 
Farther on political arguments favouring Polish integration with the EU, one must emphasize that being a member of the EU makes a given country's level of safety higher first of all in economic and later in military sense. Acharacteristic sense of belonging to the West, not to the East is of crucial importance to the Polish people. The Union, or previously Communities, were formed not only to facilitate trade among member states but integration processes were also accompanied by characteristic spirit of solidarity, co-responsibility. In case of crisis, the countries could count on one another ${ }^{8}$. Membership in the EU turned out to be a perfect insurance against storms in world economy and against protectionism tendencies that have appeared in the world in connection with ongoing crisis since 2008. For many years it has been tried to increase the military security of member states. There are actions aiming at forming common defense policy and there are already common forces of fast and critical reaction (though rather minor and of limited operational capacities). The Lisbon Treaty includes regulations about the necessity to support militarily any member state that has been attacked by a third party'. However, the reinforcement of these regulations and their transformation into real operational capacities will not be easy and it will definitely last for many years.

Finally, one should ask - if not the EU, what then? What other alternative did Poland have at that time? Swiss or Norway model was out of the question as Poland was far behind those countries in terms of social and economic development. Poland simply could not afford it; we did not have energy sources that we could export, nor did we have a service sector as well developed as in Switzerland or Norway. What was left, then? Belarus or Ukraine model? One can clearly see now what might have happened if Poland had not joined the $\mathrm{EU}^{10}$. Various prognoses and scenarios prepared by economists leave no doubt that lack of accession would have resulted in slow economic growth, lower GDP and smaller export growth as well as lower expenditures on investments and higher unemployment ${ }^{11}$.

pl/pl/polityka_zagraniczna/zagraniczna_polityka_ekonomiczna/wieloletnie_ramy_finansowe/, (accessed 5.08.2014).

8 For example, gas delivery when it stopped coming to Europe as a result of Ukraine-Russia conflict in 2009, financial help protecting Greece against bankruptcy, etc.

9 More on this topic among others [in:] art. 24, art. 28 par. 1, art. 38 . art. 42-46 of Consolidated version of the Treaty on European Union and art. 2 par. 4, art. 222 of Consolidated version of the Treaty on the functioning of the European Union, OJ C 326, 26.10.2012.

10 It is enough to say that Belarus is isolated on international arena, and there is a military conflict in Ukraine - the authorities against pro-Russia separatists and Russia itself, which already caused Crimea annexation to Federation of Russia (not accredited by the West)

11 See: MSZ, Polskie 10 lat w Unii. Raport, Warszawa 2014, pp. 217-222. 


\section{Social arguments}

Let us focus now on social benefits put forward by those in favour of European integration. The most common argument here is abolition of borders. It is a fact that the Poles can freely and without any limitations travel all over united Europe. They do not need passports, visas while doing so and all this is possible thanks to membership in the Schengen Area ${ }^{12}$. It is worth mentioning that Poland as the east border of the EU is now responsible for protecting and reinforcing the control of people and goods that enter the EU and come from third countries. We have not been left without any support in this respect, however. We make use of perennial experiences of our German partners and we gained access to EU funds spent on this purpose ${ }^{13}$. To show trust in us and emphasize our importance in this sphere the registered office of Union agency - Frontex has been located in Warsaw. The European Agency for the Management of Operational Cooperation at the External Borders of the Member States of the European Union is responsible for border service training, analyzing the threat of terrorism risk and supporting member states in expelling illegal immigrants ${ }^{14}$.

Secondly, it is worth mentioning at this point that Poland's joining the EU caused many positive changes on the employment market. Being a member of the EU, Poland was forced to introduce some reforms in employment systems ${ }^{15}$, give financial help to the unemployed and people in danger of losing jobs as well as in danger of social exclusion ${ }^{16}$. After transitional periods, the job markets in the "old" member states were opened for Polish people ${ }^{17}$. One the whole, the unem-

12 Poland was admitted to the Schengen Zone on 21 December 2007 (land and sea border) and on 30 March (air border) See: art. 46 Ustawy z dnia 24 sierpnia 2007 roku o udziale Rzeczypospolitej Polskiej w Systemie Informacyjnym Schengen oraz Informacji Wizowej, Dz.U. RP z 2007 roku nr 165 poz. 1170; art. 1 of Council Decision of 6 December 2007 on the full application of the provisions of the Schengen acquis in the Czech Republic, the Republic of Estonia, the Republic of Latvia, the Republic of Lithuania, the Republic of Hungary, the Republic of Malta, the Republic of Poland, the Republic of Slovenia and the Slovak Republic, OJ L 323, 08.12.2007.

13 See: M. Droździkowska, Schengen z perspektywy polskich doświadczeń, [in:] Polska w strefie Schengen. Refleksje po pierwszym roku członkostwa, ed. B. Radzikowska-Kryśczak, A. Sadownik, Warszawa 2008, pp. 10-13.

14 Link to official website: http://frontex.europa.eu/, (accessed 6.08.2014).

15 It was much easier as Poland or, to be more specific, Polish institutions of the employment market gained access to European funds from among others: Community Programme for Employment and Social Solidarity (Progress), which is now called European Union Programme for Employment and Social Innovation (EaSI).

16 Among others from European Social Fund and European Globalisation Adjustment Fund.

17 On 1 May 2004 only Great Britain, Ireland and Sweden did not introduce limitations on employing the Poles in their countries. Later on, more EU countries followed: a. Spain, Portugal, Greece, 
ployment has been decreasing for the past 10 years to be about 13.4\% (in 2004 it was 19\%). Additionally, there has been growth in security of consumer rights, especially their health, safety and economic interest as the EU gives substantial weight to consumer policy and considers it to be one of the key elements of effective functioning of the common market ${ }^{18}$.

Table 1. The unemployment rate in Poland in the years 2004-2013 $3^{19}$

\begin{tabular}{|c|c|c|c|c|c|c|c|c|c|c|}
\hline & $\mathbf{2 0 0 4}$ & $\mathbf{2 0 0 5}$ & $\mathbf{2 0 0 6}$ & $\mathbf{2 0 0 7}$ & $\mathbf{2 0 0 8}$ & $\mathbf{2 0 0 9}$ & $\mathbf{2 0 1 0}$ & $\mathbf{2 0 1 1}$ & $\mathbf{2 0 1 2}$ & $\mathbf{2 0 1 3}$ \\
\hline GUS & $19.5 \%$ & $17.6 \%$ & $14.8 \%$ & $11.2 \%$ & $9.5 \%$ & $12.1 \%$ & $12.4 \%$ & $12.5 \%$ & $13.4 \%$ & $13.4 \%$ \\
\hline Eurostat & $19.1 \%$ & $17.9 \%$ & $13.9 \%$ & $9.6 \%$ & $7.1 \%$ & $8.1 \%$ & $9.7 \%$ & $9.7 \%$ & $10.1 \%$ & $10.3 \%$ \\
\hline
\end{tabular}

Source: Central Statistical Office of Poland (GUS), Roczne wskaźniki makroekonomiczne - Rynek pracy, http://stat.gov.pl/wskazniki-makroekonomiczne/; Eurostat, Unemployment rate by sex and age groups - annual average (\%), http://appsso.eurostat.ec.europa.eu/nui/show.do?dataset=une_ rt_a\&lang=en, (accessed 8.08.2014).

Thirdly, among social arguments in favour of Poland's joining the EU is the one of incredible opportunity for Polish scientific and research sector as well as higher education sector to take a qualitative leap. Both students and teaching staff gained access to European programmes of scientific exchange ${ }^{20}$, participation in international teams and research projects (e.g. European Research Area), research funds or access to brand new research infrastructure and modern technologies ${ }^{21}$.

Finland (and Iceland) - 1 May 2006; b. Italy - 31 July 2006; c. The Netherlands - 1 May 2007; d. Luxembourg - 1 November 2007; e. France - 1 July 2008; f. Belgium, Denmark (and Norway) 1 May 2009; g. Germany, Austria - 1 May 2011; h. Switzerland - 1 May 2014. See: M. Piątkowska, Jak się Europa przed Polakiem otwierała, http://gazetapraca.pl/gazetapraca/1,67527,9535543,Jak_ sie_Europa_przed_Polakiem_otwierala.html, (accessed 8.08.2014).

18 This can be proved in, for example, art. 169 of Consolidated version of the Treaty on the functioning of the European Union, OJ C 326, 26.10.2012. Adaptation of it on practical action is among others Programme of Community action in the field of consumer policy (2007-2013), continued in the years 2014-2020 and called Multiannual consumer programme for the years 2014-2020.

19 The differences in statistical data on unemployment rate in Poland given by Central Statistical Office of Poland (GUS) and Eurostat are result of different definitions of "an unemployed person" and a different methodology of data collection. See: Bezrobocie w Polsce wg Eurostatu $i$ GUS-u. Skąd takie rozbieżności?, http://www.bankier.pl/wiadomosc/Bezrobocie-w-Polsce-wg-Eurostatu-iGUS-u-Skad-takie-rozbieznosci-2771596.html, (accessed 9.08.2014).

20 There were some in the past, among others: Erasmus, Youth in Action, Lifelong Learning Programme; and in the years 2014-2020 the programme which will replace them is called Erasmus+: the Union programme for education, training, youth and sport.

21 Previously these were: VI Framework Programme, VII Framework Programme and now it is beginning Horizon 2020 - the Framework Programme for Research and Innovation (2014-2020). 
Indirectly, such factors contribute to upgrading of qualifications and skills of both students as well academic staff.

Finally, the fourth argument for Poland's integration with the European Union. If just before the accession and straight after it the level of euroscepticism among Polish people was relatively high (25-40\%), the past 10 years of our existence in European structures have made a significant increase in social support for the EU and its actions. We have a high opinion of EU influence on Polish economy as well as on agriculture or security ${ }^{22}$. The Poles consider themselves citizens of the EU (77\% of those surveyed as opposed to the average EU-28 at the level of 65\%); they also claim to know their European rights (60\% of those surveyed as opposed to the average EU-28 at the level of 48\% $)^{23}$. Generally, the surveys show that the percentage of support for the EU is very high in Poland (82\% in May 2014) and it is the highest of the whole $\mathrm{EU}^{24}$. What is more, the Poles also think that membership in the EU gives Poland far more benefits than drawbacks - in February 2014, $62 \%$ of those surveyed claimed so; $20 \%$ claimed that benefits cover the costs; and only $13 \%$ claimed that there are more costs and threats of Poland's membership in the EU. To make it clear, it must be added that such results have remained on more or less the same level since $2007^{25}$.

\section{Economic arguments}

Let us now focus on economic benefits of Polish integration with the European Union. It is in this sphere where one could notice the biggest amount of positive effects. Firstly, the access to common market was and is for Poland a chance to increase the pace of economic growth, upgrade its innovation and competitiveness on international markets. It is enough to say that Polish GDP has nearly doubled in that time $(2003-843 \text { billion zlotys, } 2013-1636 \text { billion zlotys })^{26}$

22 See: MSZ, Polskie 10 lat..., pp. 210-216.

23 See: Public Opinion in the European Union, Standard Eurobarometer, 2014, No. 81, p. 29 and 31 .

24 See: Public Opinion Research Center (CBOS), Stosunek do członkostwa Polski w Unii Europejskiej, http://www.cbos.pl/PL/trendy/06_stosunek_do_integracji_UE_tabela.php, (accessed 10.08.2014).

25 See: CBOS, 10 lat członkostwa w Unii Europejskiej, Komunikat z badań, 2014, No. 52, p. 5.

26 Increase from the level of 216.8 billion dollars in 2003 to 517.54 billion dollars. See: World Bank, GDP (current US\$), http://data.worldbank.org/indicator/NY.GDP.MKTP.CD, (accessed 10.08.2014). By contrast, GUS gives the following data: 843.15 billion zlotys in 2003 and 1635.75 billion zlotys in 2013. See: GUS, Roczne wskaźniki makroekonomiczne - Rachunki narodowe PKD 2007, http://stat.gov.pl/wskazniki-makroekonomiczne/, (accessed 11.08.2014). 
and per capita gross domestic product (GDP) measured in purchasing power parities of the Community average increased from 49\% before the accession to $68 \%$ at present ${ }^{27}$. This was possible thanks to strong support of the EU structures for the development of small and medium-sized enterprises in our country ${ }^{28}$. This sector is perceived in the EU as the key one for a successful economic growth of the whole Community in the perspective up to 2020. Bearing this fact in mind, Polish enterprises have a unique opportunity to modernize, establish and develop cooperation with their equivalents located in other member states.

Secondly, the abolition of customs duties, tariff and non-tariff barriers (e.g. the elimination of border control, technical limitations, reduction of transport costs, bank and insurance services) contributed to a vast increase of trade exchange with the EU countries (from 38.4 billion euro in 2003 to 114 billion euro in 2013) ${ }^{29}$. What happened was a scientifically defined trade creation effect that is trade expansion with countries belonging to customs union as a result of new exchange channels. The size of the common market (approx. 510 million citizens) is not irrelevant here. The third countries also appreciated Polish economic reliability, which can be proved by the export increase to them from approx. 9 billion euro in 2003 to 38.6 billion euro in 2013 . The increase of trade exchange usually leads to rise in employment in export oriented enterprises and developmental investments (innovation and competitiveness), which gradually lead to restructuring of the whole Polish economy ${ }^{30}$.

Thirdly, one more benefit of Polish integration with the EU is increase of safety of economic trade and capital flows, which is a result of partners confidence growth, macroeconomic stability of Poland and the country's investment attractiveness. This means bigger reliability of Polish companies in other member states and more importantly, rise in foreign direct investments in Poland. The amount of FDI in Poland rose from 54.7 billion dollars in 2003 to 176.52 billion dollars in 2012 (there is no more current data) ${ }^{31}$. Thanks to such vast inflow of invest-

27 See: Eurostat, GDP per capita in PPS, http://epp.eurostat.ec.europa.eu/tgm/table.do?tab=ta ble\&init=1\&plugin=1\&language=en\&pcode=tec00114, (accessed 11.08.2014).

28 For example, structural funds, COSME - Programme for the Competitiveness of Enterprises and small and medium-sized enterprises (in the previous perspective known as Competitiveness and Innovation Framework Programme 2007-2013), Jeremie initiative, activity of European Investment Bank.

29 See: MSZ, Polskie 10 lat..., pp. 75-81.

30 See: The official website of the President of the Republic of Poland, Cztonkostwo Polski w Unii Europejskiej, http://www.prezydent.pl/aktualnosci/polska-w-ue/czlonkostwo-w-ue/strona, 2.html, (accessed 12.08.2014).

31 The author's calculations based on statistical data published by National Central Bank (NBP), Inwestycje bezpośrednie - zagraniczne, http://www.nbp.pl/homen.aspx?f=/en/publikacje/ 
ments they became a significant factor supporting Polish economic growth and increasing innovation and competitiveness of economy; they also to some extent contributed to unemployment reduction. It is worth mentioning that the size of Polish cumulative foreign direct investments is still growing - from 1 billion dollars in the year of 2000, 6.28 billion dollars in 2005 to 27.7 billion dollars in 2009 (no more current data) ${ }^{32}$.

Another very important argument in favour of Poland's integration with the EU, both from the citizens' and economy's perspective, is a wide flow of euro coming to our country from Brussels. Between 1 May 2004 and 30 June 2014 it was - according to Polish Ministry of Finance - 102.4 billion euro, when the opposite flow was just over 33.7 billion euro. It is then easy to count that balance is definitely favourable to Poland and is at the moment nearly 68.7 billion euro ${ }^{33}$. It is worth noticing that the percentage of the use of the EU funds for Poland is high and Poland is among the EU leaders in this respect ${ }^{34}$.

Next, so far Poland has received 64.7 billion euro (1 May 2004 - 30 June 2014) as EU funds on investments under the cohesion policy, especially on the social and economic development of regions, transport and energy infrastructure, environmental protection, development of cities, small and medium-sized enterprises or reinforcement of human capital. Naturally, there are more spheres of support and it is impossible to enumerate them all here. Additionally, another EU financial perspective is just beginning where up till the year of 2020 more 82.5 billion euro is about to flow into Poland. Again Poland is the biggest net recipient of the EU cohesion policy funds. This argument of those in favour of the EU is strong and measurable and surely almost every Polish citizen can see these financial contributions in their local areas (since 2004, more than 160 thousand projects have been accomplished and more 20 thousand projects are about to be finished soon). Ultimately, all these investments are to create economy based on

ziben/ziben.html, (accessed 12.08.2014); and [in:] W. Karaszewski, Bezpośrednie inwestycje zagraniczne. Polska na tle reszty świata, Toruń 2004, p. 191.

32 Author's calculations based on data published by National Central Bank., Inwestycje bezpośrednie - polskie, http://www.nbp.pl/home.aspx?f=/publikacje/pib/pib.html, (accessed 12.08.2014); and [in:] Aktywność inwestycyjna polskich przedsiębiorstw za granica w postaci inwestycji bezpośrednich. Raport $z$ badania, Toruń 2009, p. 4.

33 See: Ministry of Finance (MF), Transfery finansowe Polska-Unia Europejska, http://www. mf.gov.pl/documents/764034/1007802/TABELA+TRANSFERY+CZERWIEC+2014.pdf, (accessed 13.08.2014).

34 See: European Commission, Bar chart Funds Absorption Rate 2014, https://cohesiondata. ec.europa.eu/EU-Cohesion-Funding/Bar-chart-Funds-Absorption-Rate-2014/g67v-zjyr?, (accessed 13.08.2014). 
knowledge, with low unemployment rate and ability to attract investors as well as to reinforce and sustain economic growth in Poland ${ }^{35}$.

Since the accession, the EU funds have been contributing to changes on the Polish countryside. According to many experts, instruments and mechanisms of the Common Agricultural Policy of the EU including direct subsidies (17.9 billion euro) and the Rural Development Programme (nearly 13.5 billion euro) positively influence farm incomes, modernization and consolidation of farms, and thus improve material situation of farmers. The countryside itself is changing as well due to investments in education and culture sector, roads, environmental protection or diversification of people's livelihood. The same is in the case of areas dependant on fishing and fishery (over 685.9 million euro) ${ }^{36}$.

Having taken into consideration the current situation behind the eastern border of Poland, one must realize that the EU legislation has led to serious changes in Polish energy sector including possessive and pro-competitive changes. The most important, however, is the growth of energy security. Although the whole idea of EU energy solidarity is right, it is yet far from being implemented (e.g. the issue of constructing the North Stream excluding Poland and despite Polish objections, possible ban on mining shale gas on the area of the EU). However, there is a system of obligatory liquid fuels reserves, there have been various gas pipelines, fuel and energy connections with neighbouring countries built to fight potential results of breaks in sources delivery from Russia. Finally, a gas port is being built with the EU funds to import this source from third countries ${ }^{37}$. At this point, it should be pointed out that natural environment in Poland and its system of protection is constantly improving. The air, water and soil are getting cleaner and cleaner and all these without a risk of decreasing the pace of economic growth and though this means considerable financial expenses.

35 See: MF, Transfery finansowe...; Ministry of Infrastructure and Development (MIR), Fundusze Europejskie 2014-2020 - informacje ogólne, http://www.mir.gov.pl/fundusze/fundusze_europejskie_2014_2020/strony/start.aspx, (accessed 14.08.2014); The Chancellery of the Prime Minister, Premier podsumowat 10 lat Polski w Unii Europejskiej, https://www.premier.gov.pl/wydarzenia/aktualnosci/premier-podsumowal-10-lat-polski-w-unii-europejskiej.html, (accessed 14.08.2014).

36 The situation present at the end of June 2014. See: MF, Transfery finansowe...

37 See: Ministry of Economy (MG), Polityka energetyczna Polski do 2030 roku, http://www. mg.gov.pl/files/upload/8134/Polityka\%20energetyczna\%20ost.pdf, (accessed 9.08.2014). 


\section{Major negative aspects of Polish membership in the EU}

Let us discuss the arguments put forward by Polish eurosceptics and opponents of the European integration. At first, it must be pointed out that it is much harder to clearly classify these arguments and they are usually a combination of political, social and economic factors. Most of the time they have heterogeneous assorted nature. Coming back to the main topic of the paragraph, one of the first arguments is that the EU expands its competences too excessively and interferes in countries' own competences too much ${ }^{38}$. One could hear such opinions even during the last election campaign for the European Parliament ${ }^{39}$. The opinion polls prove that such slogans are quite popular in Poland as the matter of losing national autonomy is the only thing that Polish citizens fear of (approx. 20-25\%) ${ }^{40}$. Such lack of autonomy in decision making, subordination to decisions made in Brussels as well as too many legal regulations often too detailed make Polish people confused and opposed. Additionally, there is lack of social support for introducing euro in Poland as the people surveyed believe that this will mean loss of autonomy and higher costs of living ${ }^{41}$.

Many people argue that Poland is somehow limited by the EU and that without it more investments would have been accomplished and they would have been less expensive and easier to do. It is also claimed that still not the best condition

38 It is important to emphasize that the EU does not take anything away. It is the member states which decide for themselves if they cede some of their powers to the Community, nobody forces them to do so. What is more, the construction of the EU decisive system that is a) running of the legislative procedures; b) allocation of exclusive competences between countries and the EU, and creation of the shared competence catalogue; c) providing legislative institutions (the main one is the Council of the European Union where it is possible to block any decisions that threaten national interests) as well as creation of the procedure of leaving the EU etc. prove that the autonomy of any country within the EU is not threatened.

39 In the last EU Parliament elections political parties proclaiming anti-EU ideas or the ideas of stopping the EU expansion gave gained popularity and brought many deputies to this institution - in Poland, anti-EU Nowa Prawica (4 MEPs) and Prawo i Sprawiedliwość (sceptics, 19 MEPs). See: Obwieszczenie Państwowej Komisji Wyborczej z dnia 26 maja 2014 roku o wynikach wyborów posłów do Parlamentu Europejskiego przeprowadzonych w dniu 25 maja 2014 roku, Dz.U. RP 2014, No. 692.

40 According to CBOS, percentage of people who think that membership in the EU limits Polish autonomy and independence is 36\%. See: CBOS, 10 lat członkostwa..., p. 22.

41 The only member states where the majority of citizens are against Economic and Monetary Union including the introduction of euro are: Great Britain (73\% - no votes and 16\% - yes votes), Sweden (77\% against 19\%), the Czech Republic (73\% against 24\%), Denmark (66\% against 29\%), Poland ( $47 \%$ against $37 \%)$ and Bulgaria ( $42 \%$ against $41 \%)$. None of these countries is a member of the euro area. 
and structure of Polish economy and poor (though improving) condition of technical infrastructure will cause a necessity to invest more in order to meet the EU requirements. It is about among others renewable energy resources, investments on research and science, reduction of importance of big mining and industrial companies (so called polluters), modernization of transport networks etc. Allegedly, Poland cannot afford all these ${ }^{42}$, especially regions and cities which are high credit burdened and a possible lack of investments can be punished with severe fines. Moreover, many critics say that ecological standards set by the EU are too high and sometimes unnecessary, which make some investments much more difficult to accomplish (e.g. Augustów ring road across the Rospuda Valley, possible ban on shale gas exploitation) ${ }^{43}$.

Sceptics and critics of the EU also claim that it unnecessarily touches upon spheres which do not concern it as it was set up as an economic organization. One of the biggest threats here is the interference in personal beliefs of outlooks on life. They oppose the alleged enforcement of political correctness or "oddities" (drug legalization, euthanasia and abortion, homosexual marriages ${ }^{44}$. Quite probable is also a threat of losing national identity or a threat of Islam ${ }^{45}$.

Critics of Polish membership in the EU prove that a high economic growth of Poland, so often cited by the government and shown by the statistical data of GUS or Eurostat, is if not totally apparent then definitely not that high. They admit that the statistics show that GDP per capita in terms of purchasing powers standards has risen but not that much. Why not? Firstly, this is the case because in western countries there has been stagnation or even economic recession, which low-

42 See: P. Swianiewicz, J. Łukomska, Kto żyje na kredyt - ranking zadtużenia samorządów, http:// www.wspolnota.org.pl/rankingi/zadluzenie-jednostek-samorzadowych/2012/, (accessed 9.08.2014); I. Sudak, Ranking najbardziej zadtużonych miast w Polsce, http://poznan.gazeta.pl/poznan/1,36001, 14619544,Ranking_najbardziej_zadluzonych_miast_w_Polsce.html, (accessed 11.08.2014).

43 See: CBOS, 10 lat członkostwa..., p. 11.

44 In fact, the EU does not interfere in such issues, on the contrary. In Treaties there are regulations about respecting worldviews of people, churches or religious communities as well as regulations about fighting any form of discrimination. For example: art. 10, art. 19 i art. 19 par. 1 of Consolidated version of the Treaty on the functioning of the European Union, OJ C 326, 26.10.2012. Actions mentioned above are a result of autonomous decisions of particular country's government and they are no determinant for other EU members.

45 When it comes to threat of immigration or Islamisation - this is not a serious problem in Poland, though it appears in rich countries of Western Europe, for instance, France, the Netherlands or Great Britain. One example can be a rapid islamisation of state schools in Great Britain. More on this in [in:] S. Castle, In Britain, School Report Cites Division Over Islam, http://www. nytimes.com/2014/06/10/world/europe/in-britain-school-report-cites-division-over-islam.html?_ $\mathrm{r}=0$, (accessed 12.08.2014). 
ered the EU GDP average. Secondly, further enlargement of the EU, especially in 2007 when Bulgaria and Romania joined it - two poorest countries of the whole EU-28, greatly contributed to reduction of the EU GDP average. Such lowering of the EU statistics is claimed to have caused statistical not factual growth of the Polish GDP ${ }^{46}$.

The EU opponents are also very critical of the reasons for the decrease of unemployment in Poland over the last 10 years. Polish authorities and the EU itself prove that it is result of pro-development investments in enterprises and enforcement of human capital. However, there are theories that such decrease was not caused by the government actions but by borders opening and massive immigration of the Poles to look for a job and better living conditions outside Poland. The critics of the EU say that about 2-2.5 million Polish citizens ${ }^{47}$ (especially young ones) left Poland to earn for a living and this is the main reason for the decrease of the registered unemployment in Poland ${ }^{48}$.

They also argue that this is a huge loss for Poland and its economy as many emigrants will never come back - they will not work, start their own business and thus will not pay taxes or create new job places in Poland. Consequently, they will not start their families ${ }^{49}$, which will result in negative effects for public finances

46 See: Z. Kuźmiuk, Statystyczna utuda czyli wzrost gospodarczy w Polsce, http://zbigniewkuzmiuk. salon24.pl/531118,statystyczna-uluda-czyli-wzrost-gospodarczy-w-polsce, (accessed 6.08.2014); K. Kolany, Czy PKB dobrze mierzy wzrost gospodarczy?, http://www.bankier.pl/wiadomosc/CzyPKB-dobrze-mierzy-wzrost-gospodarczy-2191521.html, (accessed 6.08.2014); A. Śliwiński, Iluzja wzrostu zamiast wzrostu, http://www.monitor-ekonomiczny.pl/s17/Artyku\%C5\%82y/a84/ Cz\%C4\%99\%C5\%9B\%C4\%87_czwarta_Iluzja_wzrostu_zamiast_wzrostu.html, (accessed 6.08.2014). This argument is not totally senseless. Although the statistical effect is widely known, its is hard to undermine the fact that membership in the EU stimulates the growth of Polish GDP and thus contributes to the economic growth and the improvement of Poles' material situation.

47 See: Kolejna wielka emigracja Polaków. W 2013 wyjechato z Polski prawie pót miliona, http:// www.fronda.pl/a/kolejna-wielka-emigracja-polakow-w-2013-wyjechalo-z-polski-prawie-pol-miliona,34385.html, (accessed 7.08.2014); Kaczyński do Polaków na Wyspach: wiem, że Wasza emigracja jest przymusowa, http://niezalezna.pl/50744-kaczynski-do-polakow-na-wyspach-wiem-ze-wasza-emigracja-jest-przymusowa, (accessed 7.08.2014). GUS statistics prove that there are more than 2.1 million Poles outside the country (data by the end of 2012), [in:] GUS, Informacja o rozmiarach $i$ kierunkach emigracji z Polski w latach 2004-2012, http://old.stat.gov.pl/cps/rde/xbcr/gus/L_Szacunek_emigracji_z_Polski_lata_2004-2012_XI_2012.pdf, (accessed 8.08.2014).

48 Although it is hard to negate the fact of massive emigration, the reasons for it are debatable with few adequate scientific studies.

49 As the EU sceptics prove, Polish women in our country have one of the lowest fertility rate in Europe, whereas in, for example, Great Britain where they have top standard medical care provided and where the social and living issues are much stable than in Poland, Polish women give birth to the biggest number of children, more than any other minority. See: World Bank, Fertility rate, total (births per woman), http://data.worldbank.org/indicator/SP.DYN.TFRT.IN, (accessed 15.08.2014); 
(e.g. no tax inflow, lower consumption) or pensioner system (e.g. no social contributions). Additionally, the result of this is to be brain drain that is the flow of gifted, educated, creative, innovative people from Poland who use their potential and ideas in the countries which enable them to do so and whose education was financed by Polish tax payers ${ }^{50}$.

Finally, the critics of Polish integration with the EU point out real costs of our membership in this organization. Over the last 10 years the Poles had to hand over more than 33.57 billion euro to the common budget as a membership contribution and over 143 million euro as a repayment to the common budget ${ }^{51}$ and which could have been spent on national purposes not on saving the countries affected by crisis or a huge number of EU civil servants. The development (or as some call it overgrowth) of administration both national and Union is one more argument against the EU itself $f^{52}$.

\section{Final remarks}

At this point, the readers should be apologized. Firstly, for the fact that the author did not manage to enumerate all positive and negative arguments of Polish membership in the European Union as well as for a brief form of presenting the theses. It is hard to imagine that the problem is $100 \%$ covered on just several pages while each of the arguments could be the subject of a report or a book. The main purpose of the article was to capture the essence of the problem, not to analyze it thoroughly.

Coming back to the $10^{\text {th }}$ anniversary of Polish membership in the EU, such a big political, legal, economic or cultural step of joining intensively integrating

Eurostat, Fertility statistics, http://epp.eurostat.ec.europa.eu/statistics_explained/index.php/Fertility_ statistics, (accessed 15.08.2014); Office for National Statistics, Births in England and Wales by Parents' Country of Birth - 2012, http://www.ons.gov.uk/ons/dcp171778_325310.pdf, (accessed 15.08.2014).

50 See: K. Szczerski, O problemie bezrobocia w Polsce, http://www.szczerski.pl/wydarzenia,pokaz, 193,krzysztof-szczerski-o-problemie-bezrobocia-w-polsce, (access 03.08.2014); K. Rybiński, Pierwszy podmuch demograficznego tsunami, http://www.ekonomia.rp.pl/artykul/1117916.html, (accessed 3.08.2014).

51 See: MF, Transfery finansowe...

52 The overdevelopment of administration is an undeniable fact. It is enough to say that in 2005 in Polish administration 344941 people were employed and in 2013 - 415 114. It is true that there are more duties for administration, but employing additional 70 thousand workers seems unjustified. See: GUS, Maty Rocznik Statystyczny Polski 2014, http://stat.gov.pl/obszary-tematyczne/roczniki-statystyczne/roczniki-statystyczne/maly-rocznik-statystyczny-polski-2014,1,15.html, p. 78, (accessed 4.08.2014). 
European countries under the aegis of the European Union must have created and it still creates many emotions, hopes as well as fears. It seems that if the Poles were to decide whether they wanted the accession, the result of referendum would also be positive. Sticking to opinion polls results (high support for the EU, predominant positive effects of the integration), one could even dare say that this result would be much better. The Poles appreciate the possibility to start work or studies abroad as well as open borders. They value the EU funds contribution to improvement of infrastructure or environmental protection in Poland. Having in mind the events behind the east border or the situation of Greece, the people of Poland understand that thanks to the EU integration, they can feel safer in international and economic sense.

Nevertheless, there are people in Poland who are active critics of the EU and its actions or they totally negate them. The people who think that the accession was historical mistake. They emphasize the progressing loss of national autonomy, the EU excessive interference in inner matters and the country's, unnecessary development of bureaucracy, unequal treatment of Polish farmers. Finally, they point out that our vote, influence or role in the EU is weak and inadequate to the social and economic potential of Poland.

It is obvious that the EU membership is beneficial as well as costly for any country. It is never the case that in a particular community, here the community of member states, a Polish view will always be in $100 \%$ implemented. A proof of maturity of Polish political leaders is the ability to search and make compromises that would at least to some extent represent Polish interests. It seems that the majority of the Poles realize that. They are aware that one must give something (some autonomous competences, membership financial contribution, the adaptation of the legal system) in order to get more. Therefore, no wonder that so many people support the EU integration. The author also feels that it is the price worth paying. 